Original Research Article

\title{
A study to evaluate the analgesic activity of Origanum vulgare in mice using hot plate method
}

\author{
Siddhi Raveendran, A. V. Tilak, Shraddha Yadav*, Sayan Das, Vishwadeep Madrewar, \\ Vishwanath Kulkarni
}

Department of Pharmacology, D.Y. Patil medical college, Pimpri, Pune, Maharashtra, India

Received: 25 March 2019

Revised: 25 April 2019

Accepted: 07 May 2019

*Correspondence to:

Dr. Shraddha Yadav,

Email: drshraddha9@gmail.com

Copyright: (C) the author(s), publisher and licensee Medip Academy. This is an openaccess article distributed under the terms of the Creative Commons Attribution NonCommercial License, which permits unrestricted noncommercial use, distribution, and reproduction in any medium, provided the original work is properly cited.

\begin{abstract}
Background: The International Association for Study of pain, has defined pain as actual or potential tissue damage or described in terms of such damage. But the burden of unwanted side effects with current regimens are high. To explore the potential of Ayurveda drugs, this study is done by using Origanum vulgare. Methods: In vivo model used-Hot plate method. Origanum vulgare $(84 \mathrm{mg} / \mathrm{kg}$ p.o) was administered in mice. The analgesic activity was studied by recording the reaction time after administration of the drug at frequent intervals up to $3 \mathrm{hrs}$. The results were analysed by ANOVA and Tukey's test. P value $<0.05$ was considered as significant. Pentazocine showed statistically prolongation in the reaction time after $30 \mathrm{~min}$ as compared to Origanum vulgare.

Results: In hot plate method, pentazocine showed statistically significant increase in the reaction time after $30 \mathrm{~min}$ of administration as compared to control group. However, Origanum vulgare in a dose of $84 \mathrm{mg} / \mathrm{kg}$ showed significantly increase in the reaction time after $30 \mathrm{~min}$ of administration as compared to control group. On comparing pentazocine and Origanum vulgare, pentazocine showed highly significant increase in the reaction time after $30 \mathrm{~min}$ as compared to Origanum vulgare at $84 \mathrm{mg} / \mathrm{kg}$ dose.

Conclusions: From the present study, it was concluded that extract of Origanum vulgare exerted analgesic activity in both the models. However, it was less potent than pentazocine. Thus, Origanum vulgare can be used in mild to moderate painful conditions.
\end{abstract}

Keywords: Analgesia, Hot plate method, Origanum vulgare, Pentazocine

\section{INTRODUCTION}

Pain is defined by the International Association for the Study of Pain (IASP) 2011 and the American Pain Society (APS) 2008 as "an unpleasant sensory and emotional experience associated with actual or potential tissue damage or described in terms of such damage."

This definition describes pain as a complex phenomenon with multiple component that impacts a person's psychological and physiological functioning. ${ }^{2,3}$ It is primarily protective in nature but often causes a lot of discomfort. ${ }^{4}$ Control of pain is one of the most important therapeutic priority. Analgesia are widely used but of total number of patients who seek treatment of pain, $50 \%$ are reported to be dissatisfied with available pharmacological options. ${ }^{5}$ In addition, many of these drugs cause serious side effects. Studies have shown that opiates cause physical dependency, tolerance and addiction while NSAIDs usually cause gastrointestinal disorders. ${ }^{6}$ 
On the contrary medicines of plant origin have been used since ages with minimal adverse effects. Plants represent a large natural source of useful compounds that might serve as lead for development of novel drugs. ${ }^{7}$

Origanum vulgare is used in traditional medicine as a diuretic, stimulant, antimicrobial, anti-inflammatory, antioxidant and anticancer. ${ }^{8}$ There are several reports indicating the analgesic effect of Origanum vulgare. The present study was planned to evaluate analgesic efficacy of Origanum vulgare by hot plate method in mice.

\section{METHODS}

The study was commenced after IAEC (Institutional Animal Ethics Committee) approval was granted and is conducted in accordance with CPCSEA (Committee for the purpose of control and supervision of experiments on animals) guidelines.

\section{Study animals}

Experimentally naive mice with the following characteristics were selected for the study,

Swiss albino mice, experimentally naïve of either sex, weight 18-22 gm were selected for study. The mice were procured from animal house of Dr. D. Y. Patil Medical College, Hospital and Research Centre, Pune-18.

Study population was 24 Swiss albino mice; 8 mice in each group. Study period was January 2018 to June 2018.

\section{Animal feed}

Food

Mice were fed with commercially available 'Nutrimix Std1020' manufactured by Baramati Agro Ltd, acquired from Nutivet Life Sciences, Pune. The nutrition provided by the pellet feed was as follows: Energy: $3620 \mathrm{kcal} / \mathrm{kg}$, Crude protein: $22.15 \%$, Crude Fibre: $62.48 \%$, Ash: 5.11\%, Sand Silica: $1.15 \%$.

\section{Water}

Drinking tap water supplied by Pimpri Chinchwad Municipal Corporation was provided to the mice through the feeding bottles with stainless steel nozzle, in each cage. Food and water were replenished once daily in the morning.

\section{Animal housing}

Mice were housed in groups of four in standard big polypropylene cages measuring $40 \times 27.5 \times 13.5 \mathrm{~cm}$ which had a wire mesh top with provision for drinking water and space for pellets. Rice paddy husk was used as bedding material in each cage. They were housed under standard condition of temperature $\left(25 \pm 5^{\circ} \mathrm{C}\right)$ and relative humidity
$(55 \pm 10 \%)$ and 12/12 hour light/dark cycle. Apart from daily replenishment of food and water, they were left undisturbed.

\section{Study drugs}

Origanum vulgare (leaf extract; Jesus Heals Ayurveda Centre, Pune) was used as test drug. Pentazocine (Pharmacy, Dr. D.Y. Patil Medical College, Pimpri, Pune) was used as standard analgesic drug used in study. Pentazocine solution was freshly prepared in distilled water and given in a dose of $1.4 \mathrm{mg} / \mathrm{kg}$ i.p.

\section{Study design}

Mice were divided into three groups. Each group was assigned eight mice on a random basis.

Table 1: Study groups.

\begin{tabular}{|ll|}
\hline Groups & Drugs and dose \\
\hline I & Distilled water $(1 \mathrm{ml}$, i.p. $)$ \\
\hline II & Origanum vulgare $(84 \mathrm{mg} / \mathrm{kg}$, i.p. $)$ \\
\hline III & Pentazocine $(1.4 \mathrm{mg} / \mathrm{kg}$, i.p. $)$ \\
\hline
\end{tabular}

\section{Methods for evaluation of analgesic activity}

\section{Screening}

Prior to employing different methods to study the analgesic activity, a preliminary screening was done. Those mice showing reaction time of less than 15 seconds were included in the study. ${ }^{9}$ Analgesic activity of aqueous extract of Origanum vulgare was studied with help of Hot plate method: widely used to evaluate opioid analgesics.

\section{Procedure}

Mice weighing 18-22 $\mathrm{g}$ were used. Mice were placed on the hot plate, which consists of electrically heated surface. Temperature of the hot plate was maintained at $55-56^{\circ} \mathrm{C}$. Responses such as jumping, withdrawal of the paws and licking of the paws are seen.

The time period (latency period), when the mice was placed and until responses occurred was recorded by a stopwatch. Test drug and the standard drugs were administered intraperitoneally, and latency period was recorded after 30, 60, 90 and 120 min for each mouse. ${ }^{9,10}$

\section{Statistical analysis}

- The data was compiled and analysed with the help of statistical package, Primer of biostatistics, version 7.0

- Results were expressed as Mean \pm SD and statistical significance between means was analysed using oneway repeated measures analysis of variance (ANOVA) 
- Tukey's test was applied for multiple comparisons

- $\mathrm{P}$ value <0.05 was considered to be statistically significant

\section{RESULTS}

Figure 1 shows the results of analgesic activity of Origanum vulgare and pentazocine as compared with control. Origanum vulgare in a dose of $84 \mathrm{mg} / \mathrm{kg}$ showed statistically significant increase in the reaction time after
30 min of administration and gradually kept on increasing at $60 \mathrm{~min}, 90 \mathrm{~min}$ and $120 \mathrm{~min}$ as compared to control group.

However, on comparison, authors see that in hot plate method, pentazocine showed statistically significant increase in the reaction time after $30 \mathrm{~min}$ of administration and gradually increased at $60 \mathrm{~min}$ and $90 \mathrm{~min}$ after which there was a slight decrease in the reaction time at $120 \mathrm{~min}$ as compared to the control group.

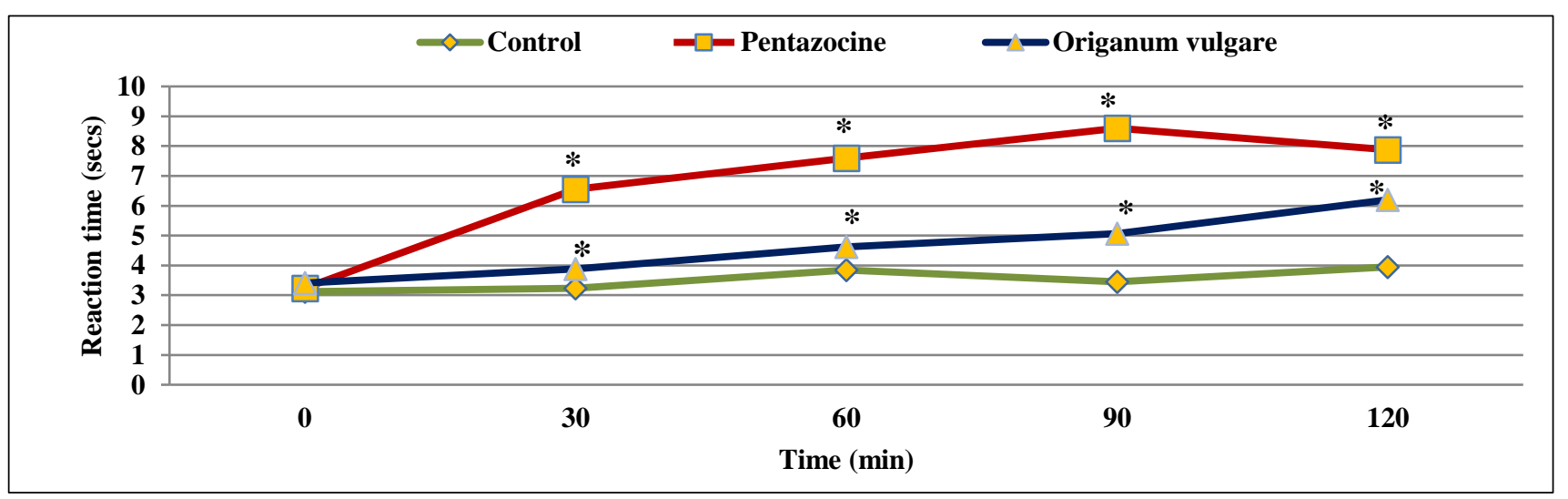

Figure 1: Results of hot plate method.

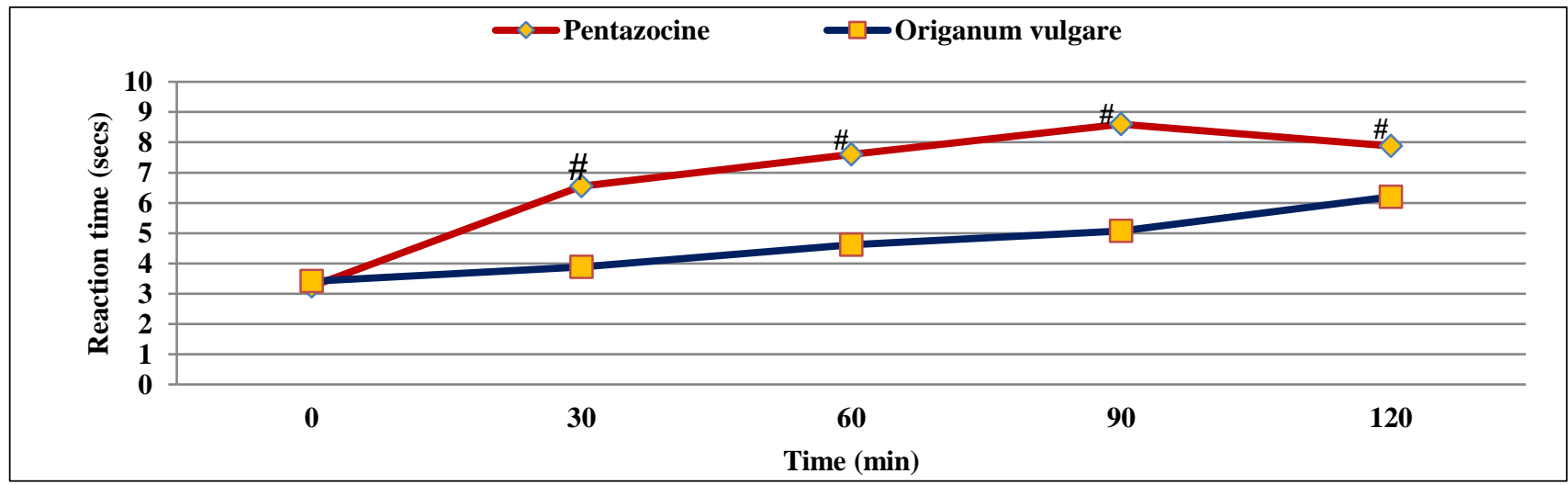

Figure 2: Results of hot plate method.

The above graph (Figure 2) shows comparison of Pentazocine and Origanum vulgare, where Pentazocine showed highly significant increase in the reaction time after $30 \mathrm{~min}$ and gradually kept on increasing at $60 \mathrm{~min}$ and $90 \mathrm{~min}$ after which there was a slight decrease in the reaction time at $120 \mathrm{~min}$ as compared to Origanum vulgare at $84 \mathrm{mg} / \mathrm{kg}$ dose.

The analgesic activity of Origanum vulgare was statistically less significant than pentazocine at all the mentioned time intervals as seen in the above graph but it was statistically more significant than the control group at all time intervals.

\section{DISCUSSION}

Analgesics are medications used to relieve pain of multiple etiology. This is generally achieved by interfering with the way the pain message is transmitted by the nerves.

The hot plate method and tail flick methods are most commonly used test for evaluation of the centrally acting analgesic drugs. The present study was carried out by using Hot plate method to evaluate the analgesic activity of aqueous extract of Origanum vulgare. 
The results f present study suggest that Origanum vulgare exhibits significant effect at dose $84 \mathrm{mg} / \mathrm{kg}$ i.p. compared to the control but when the analgesic effect of Origanum vulgare was compared with pentazocine, pentazocine exhibit significant analgesic effect as compared to Origanum vulgare.

Thus, findings of the present study are similar to the findings of study done by Arzi A et al, the latter evaluated the hydroalcholic extract of Origanum vulgare in rats by formalin test where maximum analgesic effect was seen at a sone of $600 \mathrm{mg} / \mathrm{kg}$. This analgesic effect of Origanum vulgare was less than analgesic affect exhibited by aspirin $(300 \mathrm{mg} / \mathrm{kg})$ and morphine $(2.5 \mathrm{mg} / \mathrm{kg}){ }^{11}$

Another study done Khaki $\mathrm{M}$ et al, showed that aqueous extract of Origanum vulgare possess antinociceptive activities in Tail flick test in a dose dependent manner. In addition, their findings suggest that Origanum vulgare induced antinociceptive may be medicated, at least is part by GABA receptor activation. ${ }^{12}$

It is reported that the analgesic effect of Origanum vulgare can be attributed to the compound named carvacrol. Carvacrol has an inhibitory effect on prostaglandins. Inhibition of prostaglandins cause antinociception. ${ }^{13}$

In the present study Origanum vulgare showed statistically significant increase in reaction time after 30mins of administration as compared to control group. However, pentazocine showed statistically significant increase in reaction time after 30 mins compared to control and Origanum vulgare.

Isolation, purification and characterization of active compounds of the extract was not part of this study. But further such studies are needed as the active compound may be better in efficiency as compared to standard analgesic drug.

Also, the combination of standard drug with Origanum vulgare has not been studied. But might be possible that its extract potentiates analgesic activity of standard drugs which may result in lower dosages of standard drugs and help in minimizing the undesirable effects of such drugs.

Further toxicity studies and clinical trials are needed to establish it as a drug in mild to moderate painful conditions.

\section{Funding: No funding sources} Conflict of interest: None declared

Ethical approval: The study was approved by the Institutional Ethics Committee

\section{REFERENCES}

1. Kumar KH, Elavarasi P. Definition of pain and classification of pain disorders. J Adv Clin Res Insights. 2016 May 1;3(3):87-90.

2. McCaffery M, Pasero C. Assessment of basic problems, misconceptions and practical tools. In: Pasero C, McCaffery M, editors. Pain assessment and pharmacologic management. St Louis:Mosby Elsevier;2011:13-177.

3. Herbert, Claire. Pain: Clinical manual (2nd edn) by M. McCaffrey \& C. Pasero. 1999. C. V. Mosby, St Louis. Journal of Clinical Nursing - J CLIN NURS. 9; 2000:650-650.

4. Raquibul SM, Hossain MM, Aktar R, Jamila M, Mazumder MEH, Alam MA, et al. Analgesic Activity of the Different Fractions of the Aerial Parts of Commenila Benghalensis Linn. Int $\mathrm{J}$ Pharmacol. 2010;6(1):63-7.

5. Serrano P, Lanas A, Arroyo MT, Ferreira IJ. Risk of upper gastrointestinal bleeding in patients taking lowdose aspirin for the prevention of cardiovascular diseases. Aliment Pharmacol Ther.2002;16(11):194553.

6. Hanson GR, Venturelli PJ, Fleckenstein AE. Introduction to drugs and society, Drugs and Society, Jones and Bartlett, Boston, Mass, USA, $10^{\text {th }} \mathrm{Ed}$; 2009:10.

7. Vitthalrao AM, Shanbhag T, Kumari MK, BerryKL, Shenoy S. Evaluation of anti-inflammatory and analgesic activities of alcohol extract of Kaempferia galangal in rats. Indian $\mathbf{J}$ Physiol Pharmacol. 2011;55(1):13-24.

8. Duka JA. Handbook of Medicinal Herbs. USA Maryland:CRC Press;2002:243.

9. Gupta R. Analgesic Agents. In: Gupta SK. Drug Screening Method. $3^{\text {rd }}$ Ed. New Delhi:Jaypee Brothers Medical Publishers;2016:476-497.

10. Ghosh MN. Fundamentals of experimental pharmacology. $\quad 6^{\text {th }} \quad$ Ed. Kolkata:Hilton and company;2015:46.

11. Arzi A, Aghel N, Khorasgani ZN, Motahari M. The study of analgesic effect of hydroalcoholic extract of Origanum vulgare in rat by formalin test. Toxicol Letters. 2009(189):S105.

12. Khaki MRA, Pahlavan Y, Sepehri G, Sheibani V, Pahlavan B. Antinociceptive effect of aqueous extract of Origanum vulgare L. in male rats: Possible involvement of the GABAergic system. Iran J Pharm Res. 2013;12(2):407-13.

13. Andrade L, de Sousa D. A review on antiinflammatory activity of monoterpenes. Molecules. 2013 Jan 18;18(1):1227-54.

Cite this article as: Raveendran S, Tilak AV, Yadav S, Das S, Madrewar V, Kulkarni V. A study to evaluate the analgesic activity of Origanum vulgare in mice using hot plate method. Int $\mathrm{J}$ Basic Clin Pharmacol 2019;8:1563-6. 